\title{
МОВНОСОЦІУМНА ГРАМАТИКА АНАТОЛІЯ ЗАГНІТКА
}

\section{(Загнітко А. Мовний простір граматики: монографія. Вінниця:} ТОВ «Твори», 2018. 448 с.)

В останні роки поряд із традиційними жанрами нормативних академічних, вишівських, шкільних граматик з'явилися «функціональна граматика» (О. Бондарко, I. Вихованець, К. Городенська, А. Загнітко) «асоціативна граматика» (Ю. Караулов), «комунікативна граматика» (І. Вихованець, А. Загнітко, Г. Золотова), «лексична граматика» (А. Шарандін), «креативна граматика» (О. Ремчукова), «поетична граматика» (І. Ковтунова, О. Скоробогатова), «граматика оцінки» (Т. Космеда, О. Халіман), «потенційна граматика» (Б. Норман). Д. Крістал (D. Grystal) видав новаторську монографію під назвою «Rediscover Grammar» («Вільна граматика») (1995), а американський лінгвіст Ф. Ньюмайер (F. Newmeyer) назвав свою граматику «Grammar is Grammar, and Usage is Usage» («Граматика - це граматика, а вживання - це вживання») (2003). Очевидно, традиційна граматика сьогодні вже не може адекватно репрезентувати широку мовленнєву діяльність людини, тому й виникають нові підходи до опису граматичних явищ.

Абсолютно слушною є думка А. Загнітка про те, що «граматика у своїх глибинах містить багато несподіванок і відкрить» (Загнітко, 2018: 7). Тому цілком логічно виникла й «мовносоціумна граматика» Анатолія Загнітка.

Загальновідомо, що мовознавці систематично фіксують вплив соціального середовища на мову, зокрема й на граматику, i, відповідно, на багатофункційну мовленнєву поведінку в соціумі й окремої мовної особистості, і народу як носія кожної конкретної мови загалом. У своїй монографії А. Загнітко наголосив, що «...функційний статус словоформи мотивований і визначуваний мовносоціумними завданнями, що актуалізують відхилення від стандарту, нормативного усталення. Мовносоціумні чинники окреслюють актуалізацію ситуативно-комунікативних завдань, що насамперед заторкують видозміну внутрішньореченнєвих доцентрових синтаксичних зв'язків, надаючи і / чи посилюючи відцентрову силу окремих зі словоформ» 
(Загнітко, 2018: 6-7), що послідовно, переконливо та яскраво продемонстрував у своїй праці.

Рецензована монографія складається з Передмови (Загнітко, 2018: 6-9), де мотивовано потребу виникнення мовносоціумної граматики та іï завдання, трьох розділів, розлогих висновків, що подані й англійською мовою (Conclusions), великого списку літератури (нараховує понад 600 одиниць) та списку джерел (127 найменувань).

У першому розділі «Категорії, рівні та одиниці мовносоціумної граматики» (Загнітко, 2018: 9-158), що складається з дев’яти параграфів, викладені теоретико-прикладні засади мовносоціумної граматики: ідеться про динаміку семантичного наповнення валентнозумовлених компонентів, комунікативні стратегії, вияв категорії морфологічного роду іменників; розглянуто іменниково-числову категорійність у типологійно-теоретичному та типологійно-функційному аспектах; схарактеризовані семантика й структура категорії істоти та статус, структура й семантика категорії особи; грунтовно описано морфологічну й семантичну структуру категорії стану й репрезентоване поле становості. Дослідник залучає й лексикографічний вимір у проекції на системність граматичної семантики, коментує типологійні вияви силового поля категорійної семантики, подає лексикографічну інтерпретацію іменників та характеризує дискурсивні практики мовносоціумного простору прийменника.

Розділ другий «Теорія граматики: моделювання і деривація» (Загнітко, 2018: 159-218) містить шість параграфів з певними підпунктами, що робить цей розділ особливо виструнченим. Докладно розглянуто категорію локативу в структурі речення з описом конкретних моделей і типів. Автор монографії спочатку цілком доречно характеризує основні поняття, які актуалізує під час аналізу, знайомить читачів з актуальними лінгвістичними поглядами на просторові конструкції з урахуванням семантичної і структурної класифікації, описує вияв локативу в реченнєвій структурі та подає семантичні варіанти локативу, знайомить з можливостями його моделювання в реченні. Крім того, у цьому розділі докладно схарактеризовані рівні та ступені міжчастиномовних транспозицій, описана «хамелеонова» вдача деяких частин мови, що надзвичайно активно виявляється в сучасному українському дискурсі. Не оминув увагою вчений і структурну та функційну типологію синтаксичної деривації, виявивши 
універсально-типологійні модифікації і трансформації слов’янського речення. Розділ завершують узагальнені роздуми дослідника про граматичну концепцію Юрія Шевельова, яку схарактеризовано з урахуванням еволюції поглядів, що мали вияв упродовж 1940-1950 рр. XX сторіччя; крім того, викладено авторську концепцію Ю. Шевельова щодо категорійної дієслівності. Убачаємо надзвичайно велике значення цього матеріалу в тому, що відомий сучасний мовознавець популяризує погляди видатного представника українського лінгвістичного зарубіжжя XX століття, адже, на жаль, сучасні молоді українські лінгвісти не завжди можуть осмислити здобутки національної української науки, не завжди належно її вивчають і поширюють, не виявляють поваги до української граматичної традиції, тому немає й відповідної наукової тяглості.

Третій розділ «Теорія речення в сучасній граматиці» (містить 14 параграфів) найбільший за обсягом (Загнітко, 2018: 219-363), що цілком виправдано, оскільки в ньому розлого описані сучасні функційно-лінгвістичні теорії речення з урахуванням різних аспектів. Починається розділ характеристикою типологій мовно-граматичних описів речення, течій і напрямів функціоналізму з аналізом термінологічного інструментарію, що не завжди однозначно потрактовується. Автор монографії подає власне бачення функційної перспективи речення та комунікативної граматики й, зокрема, функційно-комунікативного синтаксису та функційного синтаксису в аспекті генеративізму як продовження формальних студій. А. Загнітко відповідає на питання, чи можна вважати функційну граматику такою, що базується на достатньо глобальній теорії. Дослідник актуалізує системно-функційний аспект дослідження речення та подає свої міркування щодо розвою семантико-синтаксичної граматики. Типологія категорій синтаксичної парадигматики стосується внушньореченнєвого виміру. Речення розглядається у фокусі рівнево-категорійного виміру з урахуванням еволюції наукових лінгвопарадигм, у світлі теорії предикативності та предикативного відношення у внутрішньореченнєвій структурі, крізь призму парадигмального й синтагмального вимірів, а також щодо валентно зумовлених внутрішньореченнєвих позицій та власне семантичних характеристик. Не залишилися без уваги й номінативно-односкладні речення. Окремий параграф присвячено феноменологійно-номінативній типології простого речення. 
Заслугою автора монографії $є$ й те, що він виходить за межі українського речення й висвітлює його специфіку ширше: через об'єктивну граматику власне слов'янського речення. Ідеться про рівні й категорії об'єктивної граматики слов'янського простого речення, його рівнево-ступеневу типологію граматизації. Просте слов'янське речення схарактеризовано крізь призму семантичних ролей агенса, об’єкта та інструмента, а також явища інваріантності / варіантності синтаксичного нуля; досліджено аналітичні вияви підмета й присудка та другорядних членів речення; виявлено відповідні типи синтаксичного синкретизму. Крім того, розглянуто типологію й семантику складнопідрядного слов'янського речення з урахуванням причиново-наслідкової детермінації.

Схвалення заслуговує здійснений аналіз українського складнопідрядного речення у зіставлені з реченням англійським. Зважаючи на англоцентризм світової лінгвістики, це надзвичайно актуально й перспективно.

Важливо й те, що теорія речення описана з виходом у типологію комунікативних категорій та стилістику тексту, що стало завершувальним акордом останнього розділу цієї фундаментальної монографiï.

Висновки (Загнітко, 2018: 363-366), подані й в англомовній версії (Загнітко, 2018:367-369), що дуже добре для популяризації української науки. У стислій формі автор чітко розставляє акценти, що проектує на здійснений аналіз, засвідчуючи, що його мовносоціумна граматика грунтується на методологічних засадах і функціональної, і комунікативної, і асоціативної, і лексичної, і креативної граматик. Дослідник наголошує, що «дискурсивні дослідження, становлення теорії мовленнєвих актів, комунікативних жанрів, аналіз особливостей мовної картини світу та багато іншого покликали до життя формування і становлення теорії активної і пасивної граматики з грунтовним вивченням асоціативних інтенцій мовної і / чи мовленнєвої особистості. [...] Лінгвосоціумні студіювання з їх активним освоєнням територіальних і соціальних анклавів привнесли розгляд мовних портретів окремих корпоративних груп і ландшафтних просторів - сіл, селищ, містечок, міст та ін. У цьому разі граматичні дослідження концентровано на теоретико-прикладних постулатах мовносоціумної граматики, визначення статусу тієї чи тієї категорійності в загальномовному 
просторі зі встановленням системного, узусного й оказіонального характеру розглядуваних явищ» (Загнітко, 2018: 364).

Основою концепції рецензованої монографії $є$ думка про те, що дискурсивна зумовленість граматичної одиниці, особливо синтаксичної (ії спроможність функціювання в певних соціумних, жанрових, стильових межах) однозначно впливає на ступінь і характер іiі граматичної організації, тобто на ії структурованість. Це значить, що ознакою висловлювання повинна бути не лише структурна організація, але й дискурсивна потреба, висока реалізованість у відповідному мовному просторі, адже граматичні явища неоднозначно розподіляються за сферами мовленнєвої діяльності. Граматика ж орієнтується на певний тип дискурсу. У цьому разі ії називають об'єктивною, або реальною граматикою, що блискуче продемонстрував Анатолій Загнітко. Учений показав це на добре дібраному й переконливому ілюстративному матеріалі: художні, публіцистичні, зокрема й еgoтексти, наукові тексти гуманітарного спрямування, малі (прислів’я, приказки) й великі літературні жанри (романи, повісті), прозові, драматургічні й поетичні тексти, що охоплюють великий часовий простір - від І. Франка, Л. Глібова до Юрія й Софії Андруховичів, Люко Дашвар.

Слід заважити, що в монографії продемонстровано широку наукову інтертекстуальність: список використаної літератури - понад 600 найменувань. Серед авторів і класики українського й зарубіжного мовознавства, і представники українського зарубіжжя, і праці сучасних відомих і маловідомих, молодих українських і зарубіжних мовознавців, зокрема й представників англомовного світу.

Новаторство А. Загнітка полягає в тому, що він показав відмінність між канонічною граматикою й граматикою об'єктивною, що враховує відповідні дискурсивні умови, різні види дискурсивної практики. Особливість запропонованого опису зумовлена надзвичайною широтою, обсягом досліджуваного об'єкта, що є живим механізмом, з великим потенціалом варіативності, і саме ці чинники $€$ тим фактором, що ускладнює можливість побачити в ньому систему, але А. Загнітко намагався це надважке завдання зреалізувати. Перед нами вдала спроба аспектуального опису об'єктивної граматики сучасної української мови, що, до речі, грунтується на великому 
авторському доробку (у списку літератури знаходимо 31 авторську працю: монографії, словники).

Для кращої орієнтації читача в текстовому просторі монографії, як видається, варто було б укласти іменний і предметний покажчики, що, однак, легко виконати під час перевидання цієї монументальної й надважливої праці.

Мова монографії не викликає зауважень, а навпаки, стиль викладу прозорий, про складне написано глибоко, просто й переконливо, а це дає змогу стверджувати, що монографія розрахована на широке коло мовознавців різного рівня - студентів, аспірантів, докторантів та метрів лінгвістичної науки.

Космеда Тетяна Анатоліївна - доктор філологічних наук, професор, Університет імені Адама Міцкевича в Познані (Польща). 61-874 Poznan, Al. Niepodległości 4.

tel. +380505168211

E-mail: tkosmeda@gmail.com

https://orcid.org/0000-0001-8912-2888

Kosmeda Tetiana Anatoliivna - Doctor of Philology, Professor, Adam Mitskevych University. Al. Niepodległości 4, Poznan, 61-874, Poland

Надійшла до редакції 03 жовтня 2019 року 